\title{
Unexpected bilateral massive pulmonary embolism
}

\author{
Zaffer Qasim
}

\section{Case report}

A 59-year-old woman with a past history of rheumatoid arthritis arrived in our Emergency Department via ambulance. Her husband stated she had suddenly "appeared very strange" whilst preparing to go out for the afternoon, but could not identify specific symptoms. Physical examination showed her to have sinus tachycardia and tachypnea, but little else of note. Her oxygen saturations however rapidly dropped when she was taken off high-flow oxygen. Her D-dimer assay was markedly elevated, and urgent computed tomographic pulmonary angiography (CTPA) was performed (Figures 1 and 2). This showed large emboli (black arrows) in both the left (Figure 1) and right (Figure 2) pulmonary arteries (white arrows), with a saddle embolus noted on the right. Following the CTPA, she developed signs and

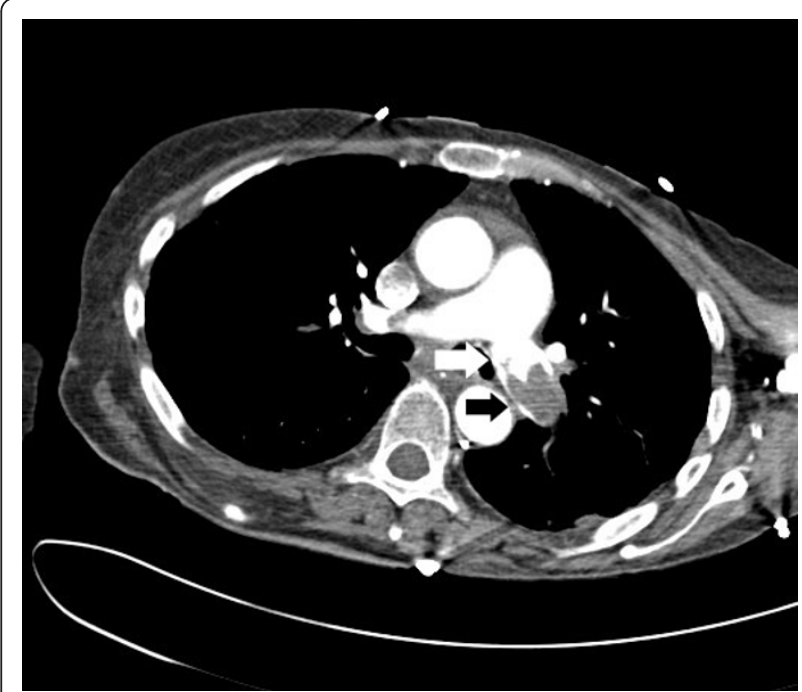

Figure 1 CTPA image of left pulmonary artery showing saddle embolus (black arrows).

Correspondence: zaffer_qasim@yahoo.com

Emergency Department, Manchester Royal Infirmary, Oxford Road, Manchester M13 9WL, UK

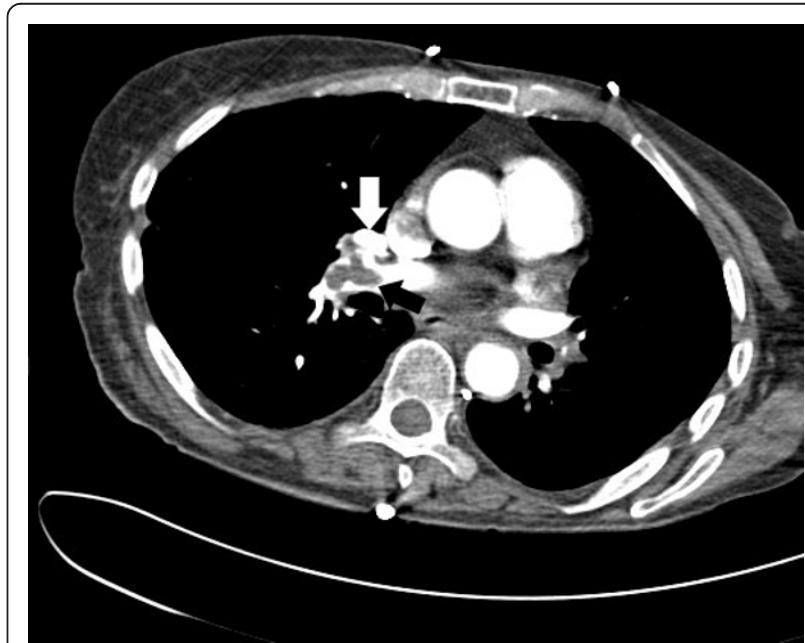

Figure 2 CTPA image showing similar saddle embolus (white arrows) in right pulmonary artery of the same patient.

symptoms of obstructive shock, requiring urgent thrombolysis using tenectaplase and admission to the intensive care unit. Her hospital stay was complicated by a lower respiratory tract infection, but she was discharged 17 days after her admission.

Rheumatoid arthritis may be complicated by venous thrombotic disease with up to $33 \%$ of cases being associated with antiphospholipid syndrome [1]. Antiphospholipid antibodies may have precipitated the events in our patient. When the patient's condition deteriorated, we resorted to thrombolytic therapy. There are clear indications for the administration of thromobolytic agents. The most recent recommendations from the American College of Chest Physicians [2] advise its use with evidence of hemodynamic compromise in the absence of contraindications to therapy, ideally via a peripheral vein, and utilizing a regimen with a short infusion time. There is less robust evidence to support the use of thrombolytics for high-risk, normotensive patients assessed to have a low bleeding risk, but outside these conditions, thrombolytics are not recommended.

\section{Springer}




\section{Competing interests}

The author declares no competing interests.

Received: 22 June 2010 Accepted: 18 November 2011

Published: 18 November 2011

\section{References}

1. Gladd DA, Olech E: Antiphospholipid antibodies in rheumatoid arthritis: identifying the dominoes. Curr Rheumatol Rep 2009, 11(1):43-51.

2. Kearon C, Kahn SR, Agnelli G, Goldhaber S, Raskob GE, Comerota AJ:

Antithrombotic therapy for venous thromboembolic disease: American College of Chest Physicians Evidence-Based Clinical Practice Guideline. Chest , 8 2008, 133(6 Suppl):454S-545S.

doi:10.1186/1865-1380-4-70

Cite this article as: Qasim: Unexpected bilateral massive pulmonary embolism. International Journal of Emergency Medicine 2011 4:70.

\section{Submit your manuscript to a SpringerOpen ${ }^{\circ}$ journal and benefit from:}

- Convenient online submission

- Rigorous peer review

- Immediate publication on acceptance

- Open access: articles freely available online

- High visibility within the field

- Retaining the copyright to your article

Submit your next manuscript at $\gg$ springeropen.com 